\title{
Long Term Effect of Integrated Nutrient Management on Growth and Yield of Finger Millet (Eleusine coracana G.) in Eastern Dry Zone of Karnataka, India
}

\author{
D.V. Prashanth ${ }^{1 *}$, R. Krishnamurthy ${ }^{1}$, D V. Naveen ${ }^{2}$, \\ L. Anand Kumar ${ }^{1}$, B.R. Harsha ${ }^{1}$ and M. Savitha ${ }^{1}$ \\ ${ }^{1}$ Department of Soil Science and Agricultural Chemistry, College of Agriculture, \\ GKVK, UAS, Bengaluru, India \\ ${ }^{2}$ Department of Soil Science and Agricultural Chemistry, College of Sericulture, \\ Chintamani, India \\ *Corresponding author
}

\begin{tabular}{|c|c|}
\hline & A B S T R A C T \\
\hline Keywords & \multirow{4}{*}{$\begin{array}{l}\text { A field experiment on "Long term effect of integrated nutrient management on finger } \\
\text { millet (Eleusine coracana G.) growth and yield was recorded at AICRPDA, GKVK, UAS, } \\
\text { Bengaluru, during kharif } 2018 \text { with } 8 \text { treatments, replicated thrice laid out in RCBD. The } \\
\text { results of the field experiment revealed that growth and yield parameters of finger millet } \\
\text { such as plant height }(96.53 \mathrm{~cm}) \text {, number of tillers per hill (7.60), number of ear heads per } \\
\text { hill (7.37), number of fingers per ear head }(6.61) \text {, test weight }(3.56 \mathrm{~g}) \text { and total dry mater } \\
\text { production }(82.67 \mathrm{~g} \text { per hill) were higher with the application of FYM @ } 10 \mathrm{tha}+100 \% \\
\text { RDF. The grain }\left(20.96 \mathrm{q}^{-1} \mathrm{ha}^{-1}\right) \text { and straw }\left(25.40 \mathrm{q} \mathrm{ha}^{-1}\right) \text { yield was found to be higher with } \\
\text { the application of } 10 \text { tonnes FYM ha }{ }^{-1} \text { and } 100 \% \text { RDF. This clearly indicated that } \\
\text { application of organic and inorganic sources of nutrients increases growth and yield of } \\
\text { finger millet as compare to inorganic only. }\end{array}$} \\
\hline $\begin{array}{l}\text { LTFE, INM, } \\
\text { Growth, Yield and } \\
\text { finger millet }\end{array}$ & \\
\hline Article Info & \\
\hline $\begin{array}{l}\text { Accepted: } \\
\text { 22 July } 2019 \\
\text { Available Online: } \\
10 \text { August } 2019\end{array}$ & \\
\hline
\end{tabular}

\section{Introduction}

Long-term experiments are those, which are conducted on the same set of experimental units over a sequence of years with preplanned sequence of treatments or crops or both on crop productivity, soil health and economics. Long-term fertilizer experiments provide valuable information on agricultural sustainability, environmental quality, nutrient uptake and physico-chemical changes of soil. Besides, providing information on better understanding of soil and plant processes, it also provides data on benefits to farmers, policy makers and extension functionaries. Intensive cultivation, growing of exhaust crops, use of imbalanced and inadequate fertilizers, restricted use of organic manures which have made the soils not only deficient in nutrients but also deteriorate soil health resulting decline in crop response to recommended dose of NPK fertilizers. Under such conditions, integrated nutrient management assumes greater significance and 
plays a vital role in maintenance of soil health and sustainable productivity.

A long-term fertilizer trial established during 1978 at All India Co-Ordinated Project on Dryland Agriculture, GKVK, Bengaluru provides some direction for better management of finger millet-groundnut cropping system. The continuous dressing of organic manure and crop residues could undoubtedly match the nutrient requirement of crop plants, where nutrient demands are comparatively smaller but will be inadequate under finger millet-groundnut cropping system in the long run. However, integrated use of organics, crop residues and chemical fertilizers has been found promising not only in maintaining and sustaining high productivity but also in providing stability to crop production. In this context, combination of organic with inorganic nutrients and crop residues at different levels were evaluated finger millet growth and yield as a test crop.

\section{Materials and Methods}

\section{Experimental site}

The experiment was a permanent trial under dryland agricultural project. It was initiated as a long term integrated nutrient management trial during 1978, with different nutrient levels of recommended dose of fertilizer and FYM as an organic nutrient source. Later one more source of organic manure (maize residue) was introduced during 1984 considering the reduced availability of FYM. Totally, 40 years of experimentation was maintained previously during kharif2018. Finger millet in mono-cropping was tested. The land was left fallow during summer season of all the years. The soils of Dryland Agriculture Project represent the typical lateritic area of Bengaluru plateau and belong to Vijayapura series, which is a dominant soil series of Bengaluru plateau. As per USDA classification, soils are classified as fine, Kaolinitic, isohyperthermic, Typic Kandiustalf. These soils are yellowish red, lateritic and are derived from granite-gneiss under sub-tropical semi-arid climate. They are very deep, well drained sandy clay loam occurring in nearly level to gently sloping lands. Initial physio-chemical properties of experimental soil given in Table 1 .

\section{Experimental details}

The test crop selected was finger millet, variety GPU 28. Experiment was carried out following randomized complete block design (RCBD) with 8 treatments and three replications. Treatment details are $\mathrm{T}_{1}$ : absolute control, $\mathrm{T}_{2}: 100 \% \mathrm{RDF}, \mathrm{T}_{3}: \mathrm{FYM} @ 10 \mathrm{t} \mathrm{ha}^{-1}$, $\mathrm{T}_{4}$ : FYM@10 t ha ${ }^{-1}+50 \%$ RDF, T5: FYM @ $10 \mathrm{t} \mathrm{ha}^{-1}+100 \% \mathrm{RDF}, \mathrm{T}_{6}$ : Maize residue @ $5 \mathrm{t} \mathrm{ha}^{-1}, \mathrm{~T}_{7}$ : Maize residue @ $5 \mathrm{t} \mathrm{ha}^{-1}+$ $50 \% \mathrm{RDF}, \mathrm{T}_{8}$ : Maize residue @ $5 \mathrm{t} \mathrm{ha}^{-1}+$ $100 \% \mathrm{RDF}$

\section{Sources of fertilizer's}

Two organic sources were used in our experiment such as FYM (Farmyard manure) and Maize Residue at the rate of $10 \mathrm{tha}^{-1}$ and $5 \mathrm{t} \mathrm{ha}^{-1}$ respectively. Whereas inorganic sources includes urea, DAP, MOP.

\section{Plant growth observation}

Plant growth parameters like plant height, number of tillers per plant number of ear heads per hill and numbers of fingers per ear head were recorded at harvest by employing standard procedures

\section{Yield observation}

Yield and yield attributes such as test weight, total dry mater, grain and straw yield were recorded at harvest as per standard protocol. 


\section{Results and Discussion}

Effect of long-term integrated nutrient management on growth parameters of finger millet

The results of the field experiment carried out during kharif, 2018, to study the effect of long-term integrated nutrient management on the growth parameters of finger millet are presented in Table 2.

\section{Plant height (cm)}

The results of the present investigation revealed that $\mathrm{T}_{5}$ (FYM @ $10 \mathrm{t} \mathrm{ha}^{-1}+100 \%$ RDF) recorded significantly higher values for plant height $(96.53 \mathrm{~cm})$, followed by treatment $\mathrm{T}_{4}$ (FYM @ $\left.10 \mathrm{t} \mathrm{ha}^{-1}+50 \% \mathrm{RDF}\right)$ where plant height $(80.13 \mathrm{~cm})$ was recorded, $\mathrm{T}_{8}$ (Maize residue@ $5 \mathrm{t} \mathrm{ha}^{-1}+100 \% \mathrm{RDF}$ ) $(79.43 \mathrm{~cm})$ which was on par with the treatment $\mathrm{T}_{4}$, where as absolute control recorded lower plant height $(43.33 \mathrm{~cm})$, The increase in the plant height might be due to enhanced sugar translocation and turgor pressure in plant cell that leads to cell enlargement and multiplication (Hooda (2002) and Abbasi et al., (2014).

\section{Number of tillers / hill}

The results of the present investigation revealed that recorded significantly higher values for No. of tillers/hill (7.6), followed by treatment $\mathrm{T}_{4}$ (FYM @ $\left.10 \mathrm{t} \mathrm{ha}^{-1}+50 \% \mathrm{RDF}\right)$ where (5.73), was recorded, $\mathrm{T}_{8}$ (Maize residue @ $\left.5 \mathrm{t} \mathrm{ha}^{-1}+100 \% \mathrm{RDF}\right)(5.90)$ which was on par with the treatment $\mathrm{T}_{4}$, where as absolute control recorded lower No. of tillers/hill (1.67).

Combined application of organic matter and chemical fertilizers increased number of fingers per ear head in finger millet (Gangadhar Nanda, 2015).

\section{Number of ear heads / hill}

Significantly higher values for No. of ear heads/hill (7.37) was recorded in $\mathrm{T}_{5}$ (FYM @ $\left.10 \mathrm{tha}^{-1}+100 \% \mathrm{RDF}\right)$, followed by treatment $\mathrm{T}_{4}$ (FYM @ $10 \mathrm{t} \mathrm{ha}^{-1}+50 \% \mathrm{RDF}$ ) where as absolute control recorded lower No. of ear heads / hill (1), greater availability of macro and micronutrients from FYM and inorganic sources of nutrients, which helped in acceleration of various metabolic processes (Umesh (2002), Govindappa (2003)).

\section{Number of fingers per ear head}

Significantly higher values for number of fingers per ear head (6.61) noticed in $\mathrm{T}_{5}$ (FYM @ $10 \mathrm{t} \mathrm{ha}^{-1}+100 \%$ RDF), followed by treatment $\mathrm{T}_{4}$ (FYM @ $\left.10 \mathrm{t} \mathrm{ha}^{-1}+50 \% \mathrm{RDF}\right)$ where as absolute control recorded lowest number of fingers per ear head (3.40), The possible reason could be due to $\mathrm{N}, \mathrm{P}_{2} \mathrm{O}_{5}$ and $\mathrm{K}_{2} \mathrm{O}$ which improves root growth and tillering, resulting in increase in amount of interception of photo synthetically active radiation and greater photosynthesis by crop (Gill and Singh, 1985) (Dhurandher and Tripathi, 1999).

\section{Effect of long-term integrated nutrient management on yield parameters of finger millet}

The results of the field experiment carried out during kharif, 2018, to study the effect of long-term integrated nutrient management on the yield parameters of finger millet are presented in Table 3.

\section{Test weight}

1000 seed weight of finger millet varied significantly among the different treatments. Significantly higher test weight (3.56 gm) was recorded with the application of FYM @ $10 \mathrm{t}$ $\mathrm{ha}^{-1}+100 \%$ RDF. $\left(\mathrm{T}_{5}\right)$. Kalaivanan and 
Hattab (2016) reported that the increase in 1000 seed weight might be due to rapid nitrogen mineralization from organic sources with adequate supply of inorganic nitrogen leading to increased nutrition of crop that resulted in translocation of photo-syntheses to seeds, which ultimately recorded more test weight of seeds.

\section{Total dry matter production (g hill $\left.{ }^{-1}\right)$}

The total dry matter production $\left(\mathrm{g}\right.$ hill $^{-1}$ ) varied significantly among the different treatments. Significantly higher total dry matter production $\left(\mathrm{g}\right.$ hill $\left.^{-1}\right)$ (82.67) was recorded with the application of FYM @ $10 \mathrm{t}$ $\mathrm{ha}^{-1}+100 \% \operatorname{RDF}\left(\mathrm{T}_{5}\right)$. Lower value was recorded for the absolute control $(1.11 \mathrm{~g}$ hill ${ }^{1}$ ) the positive effect of farmyard manure in increasing the nutrients uptake leading to higher dry matter production as reported by Jayabharath and Sharanappa (2003), Avinish and Kushwaha (2006).

\section{Grain and straw yield}

Significant variations were observed in grain and straw yield of finger millet between the treatments. Significantly higher grain yield (20.96 $\left.\mathrm{q} \mathrm{ha}^{-1}\right)$ and straw yield (25.46 q ha $\left.{ }^{-1}\right)$ was obtained with FYM @ $10 \mathrm{t} \mathrm{ha}^{-1}+100 \%$ RDF $\left(\mathrm{T}_{5}\right)$. The positive effect of increase in grain and straw yield of finger millet might be due higher and balanced supply of plant nutrients through organic sources and inorganic fertilizers (Rangaraj et al., 2007 and Selvamurugan et al., 2013).

Table.1 Physical and chemical properties of soil prior to the experiment in 1978

\begin{tabular}{|c|c|}
\hline \multicolumn{2}{|c|}{ Physical properties } \\
\hline Coarse sand (\%) & 42.00 \\
\hline Fine sand $(\%)$ & 30.50 \\
\hline Silt (\%) & 6.20 \\
\hline Clay $(\%)$ & 21.20 \\
\hline Textural class & Sandy clay loam \\
\hline Maximum water holding capacity (\%) & 29.40 \\
\hline Pore space $(\%)$ & 41.80 \\
\hline Volume expansion (\%) & 2.40 \\
\hline Bulk density $\left(\mathrm{Mg} \mathrm{m}^{-3}\right)$ & 1.64 \\
\hline \multicolumn{2}{|c|}{ Chemical properties } \\
\hline pH & 5.00 \\
\hline $\mathrm{EC}\left(\mathrm{dS} \mathrm{m}^{-1}\right)$ & 0.20 \\
\hline Organic carbon $(\%)$ & 0.40 \\
\hline Available nitrogen $\left(\mathrm{kg} \mathrm{ha}^{-1}\right)$ & 200.0 \\
\hline Available phosphorus (kg ha $\left.{ }^{-1}\right)$ & 8.70 \\
\hline Available potassium $\left(\mathrm{kg} \mathrm{ha}^{-1}\right)$ & 132.80 \\
\hline Exchangeable calcium $\left(\mathrm{cmol}\left(\mathrm{p}^{+}\right) \mathrm{kg}^{-1}\right)$ & 2.30 \\
\hline Exchangeable magnesium $\left(\mathrm{cmol}\left(\mathrm{p}^{+}\right) \mathrm{kg}^{-1}\right)$ & 0.75 \\
\hline Exchangeable potassium $\left(\mathrm{cmol}\left(\mathrm{p}^{+}\right) \mathrm{kg}^{-1}\right)$ & 0.30 \\
\hline
\end{tabular}


Table.2 Effect of long-term integrated nutrient management on growth and yield of finger millet

\begin{tabular}{|c|c|c|c|c|}
\hline Treatments & $\begin{array}{c}\text { Plant } \\
\text { height } \\
\text { (cm) }\end{array}$ & $\begin{array}{l}\text { No. of tillers/ } \\
\text { hill }\end{array}$ & $\begin{array}{c}\text { No. of } \\
\text { ear } \\
\text { heads/hill }\end{array}$ & $\begin{array}{c}\text { No. of } \\
\text { fingers/ } \\
\text { ear head }\end{array}$ \\
\hline$T_{1}$ : Absolute control & 43.33 & 1.00 & 1.67 & 3.40 \\
\hline $\mathrm{T}_{2}: 100 \% \mathrm{RDF}$ & 67.50 & 4.33 & 4.30 & 5.20 \\
\hline $\mathrm{T}_{3}:$ FYM @ $10 \mathrm{t} \mathrm{ha}^{-1}$ & 73.10 & 4.57 & 4.70 & 5.32 \\
\hline$T_{4}: F Y M @ 10 \mathrm{t} \mathrm{ha}^{-1}+50 \%$ RDF & 80.13 & 5.73 & 6.17 & 6.06 \\
\hline $\begin{array}{l}T_{5}: \text { FYM @ } 10 \mathrm{tha}^{-1}+100 \% \\
\text { RDF }\end{array}$ & 96.53 & 7.60 & 7.37 & 6.61 \\
\hline $\mathrm{T}_{6}$ : Maize Residue @ $5 \mathrm{t} \mathrm{ha}^{-1}$ & 61.53 & 4.37 & 4.00 & 5.07 \\
\hline $\begin{array}{l}\mathrm{T}_{7}: \text { Maize Residue @ } 5 \mathrm{t} \mathrm{ha}^{-1}+ \\
\text { 50\% RDF }\end{array}$ & 77.50 & 5.57 & 5.67 & 5.77 \\
\hline $\begin{array}{l}\text { T}_{8} \text { : Maize Residue @ } 5 \mathrm{t} \mathrm{ha}^{-1}+ \\
\text { 100\% RDF }\end{array}$ & 79.43 & 5.67 & 5.90 & 5.90 \\
\hline S.Em \pm & 3.59 & 0.32 & 0.32 & 0.30 \\
\hline CD@ $@$ 5\% & 10.89 & 0.97 & 0.99 & 0.92 \\
\hline
\end{tabular}

Table.3 Effect of long-term integrated nutrient management on yield parameters of finger millet

\begin{tabular}{|c|c|c|c|c|}
\hline \multirow[t]{2}{*}{ Treatments } & \multirow{2}{*}{$\begin{array}{l}\text { Test weight } \\
\text { (g) }\end{array}$} & \multirow{2}{*}{$\begin{array}{l}\text { Total dry matter } \\
\text { production } \\
\left(\text { g hill }^{-1}\right)\end{array}$} & \multicolumn{2}{|c|}{ Yield $\left(\right.$ qha $\left.^{-1}\right)$} \\
\hline & & & Grain & Straw \\
\hline$T_{1}$ : Absolute control & 2.03 & 1.11 & 0.94 & 1.79 \\
\hline $\mathrm{T}_{2}: \mathbf{1 0 0 \%} \mathrm{RDF}$ & 3.11 & 38.18 & 11.64 & 18.63 \\
\hline$T_{3}:$ FYM @ $10 \mathrm{tha}^{-1}$ & 3.17 & 42.17 & 12.58 & 22.18 \\
\hline $\begin{array}{l}T_{4}: \text { FYM @ } 10 \mathrm{tha}^{-1}+ \\
50 \% \text { RDF }\end{array}$ & 3.47 & 56.87 & 18.09 & 21.73 \\
\hline $\begin{array}{l}\text { T}_{5}: \text { FYM @ } 10 \mathrm{tha}^{-1}+ \\
100 \% \text { RDF }\end{array}$ & 3.56 & 82.67 & 20.96 & 25.40 \\
\hline $\begin{array}{l}\text { T}_{6}: \text { Maize Residue @ } 5 \text { t } \\
\text { ha }^{-1}\end{array}$ & 3.06 & 28.80 & 7.64 & 12.90 \\
\hline $\begin{array}{l}\text { T }_{7} \text { : Maize Residue @ } 5 \mathrm{t} \\
\mathrm{ha}^{-1}+\mathbf{5 0 \%} \text { RDF }\end{array}$ & 3.28 & 46.13 & 15.45 & 20.65 \\
\hline $\begin{array}{l}T_{8} \text { : Maize Residue @ } 5 \mathrm{t} \\
\mathrm{ha}^{-1}+100 \% \mathrm{RDF}\end{array}$ & 3.32 & 50.17 & 16.37 & 21.28 \\
\hline S.Em \pm & 0.20 & 2.77 & 0.72 & 0.99 \\
\hline CD@ $@ 5 \%$ & 0.60 & 8.40 & 2.19 & 3.01 \\
\hline
\end{tabular}

In conclusion, application of organic fertilizers along with inorganic fertilizers had positive impact on crop growth and yield of finger millet and maintained good soil health.
Among all the treatments imposed application of FYM @ $10 \mathrm{t} \mathrm{ha}^{-1}+100 \% \mathrm{RDF}\left(\mathrm{T}_{5}\right)$ was found to increase the growth and yield of finger millet. 


\section{References}

Abbasi, G., Anwar, U. H., Moazzam, J., Muhammad, A. U. H., Shafaqat, A., Ahmad, M., Akhtar, F., Muhammad, A. I., Hamid, N. K. and Muhammad, A. K., 2014, Enhancement of maize production through integrated plant nutrient management in arid climate. $J$. Pure and App. Sci., 24-33(1-2): 7-16.

Avinish Kumar and Kushwaha, H. S., 2006, Response of pigeonpea (Cajanus cajana L.) to sources and levels of phosphorus under rainfed conditions. Indian $J$. Agron., 51(1): 60-62.

Dhurandher, R. L. and Tripathi, R. S., 1999, Impact of sowing method and $\mathrm{N}$ - levels on productivity of late duration rice cultivars in Vertisol. Haryana J. Agron., 15(1): $1-5$.

Gangadhar Nanda, 2015, Effect of different compost levels and inorganics on the performance of basmati rice (Oryza sativa L.) cv. Hubr 10-9. M.Sc.(Agri) Thesis, Inst. Agri. Sci, Banaras Hindu university, Varanasi.

Gill, H. S. and Singh, H., 1985, Effect of Mixtalol and Agromix in relation to varying levels of $\mathrm{N}$ on growth and yield of paddy, PAU. J. Res.,22(4): 617-623.

Govindappa, 2003, Efficacy of different organic manures and inorganic fertilizer on growth yield of rain fed finger millet. M.Sc. (Agri.) Thesis, University of Agricultural Sciences, Bangalore.

Jayabharath, P. and Sharanappa, 2003, Composted poultry waste and fertilizer levels effect on yield and nutrient uptake of sunflower (Helianthus annuus) and residual NPK status. $J$. Oilseeds Res., 20: 129-130.

Kalaivanan, D. and Hattab, O. K., 2016, Recycling of sugarcane industries byproducts for preparation of enriched pressmud compost and its influence on growth and yield of rice (Oryza sativa L.). Int. J. Recycl Org Waste. Agricult., 5: 263-272.

Nehra, A. S. and Hooda, I. S., 2002, Influence of integrated use of organic manures and inorganic fertilizers on lentil and mung bean yields and soil properties. Res. Crops., 3(1): 11-16.

Rangaraj, T., Somasundaram, E., Mohamed Amanullah, M., Thirumurugan, V., Ramesh, S. and Ravi, S., 2007, Effect of agro-industrial wastes on soil properties and yield of irrigated finger millet (Eleusine coracana L. Gaertn) in Coastal Soil. Res. J. Agric. \& Biol. Sci., 3(3): 153-156.

Selvamurugan, M., Doraisamy, P. and Maheswari, M., 2013, Effect of biomethanated distillery spentwash and pressmud biocompost on growth, yield and quality of sugarcane.J. Int. Environmental Application and Science., 8(4): 511-519.

Umesh, M. R., 2002, Assessment of inter cropping, advantage of finger millet with castor and redgram under integrated nutrient supply levels. M.Sc.(Agri.) Thesis, University of Agricultural Science, Bangalore.

\section{How to cite this article:}

Prashanth, D.V., R. Krishnamurthy, D V. Naveen, L. Anand Kumar, B.R. Harsha and Savitha, M. 2019. Long Term Effect of Integrated Nutrient Management on Growth and Yield of Finger Millet (Eleusine coracana G.) in Eastern Dry Zone of Karnataka, India. Int.J.Curr.Microbiol.App.Sci. 8(08): 2362-2367. doi: https://doi.org/10.20546/ijcmas.2019.808.274 